\title{
A Nonsense Mutation in the Structural Gene for Glutamine Synthetase Leading to Loss of Nitrogen Regulation in Klebsiella aerogenes
}

\author{
Robert A. Bender and Linda J. Eades \\ Department of Cellular and Molecular Biology, Division of Biological Sciences, University of Michigan, \\ Ann Arbor, Michigan 48109, USA
}

\begin{abstract}
Summary. An amber mutation ( $g \ln A 3711)$, the first nonsense mutation isolated in Klebsiella aerogenes, is described. When amber suppressors were present, the mutant made active glutamine synthetase which was more thermolabile than wild type, showing that $g \ln A 3711$ lies in the structural gene for glutamine synthetase. Strains carrying the glnA3711 allele were unable to express nitrogen regulation of genes coding for histidase, asparaginase, and glutamate dehydrogenase unless amber suppressors were also present. These results support a model that expression of gene(s) from the $g \ln A$ promoter is required for nitrogen regulation in $K$. aerogenes.
\end{abstract}

Previous reports have suggested that the biosynthetic enzyme glutamine synthetase (GS) served a second role as an activator of gene expression for genes involved in nitrogen metabolism in Klebsiella aerogenes (Magasanik et al. 1974). This model was based, in part, on the observations that strains lacking GS because of mutations in the structural gene $(g \ln A)$ were unable to activate expression of genes such as hut (histidine utilization). The structural gene for GS was identified by the $g \ln A 51$ allele which results in the production of a polypeptide antigenically identifiable as GS $\left(\mathrm{CRM}^{+}\right.$phenotype) but lacking enzymatic activity (DeLeo and Magasanik 1975). Mutations causing loss of antigenic as well as enzymatic activity $\left(\mathrm{CRM}^{-}\right)$were assigned to $\operatorname{gln} A$ on the basis of tight linkage to glnA51 (Bender and Magasanik 1977). The $g \ln A 51\left(\mathrm{CRM}^{+}\right)$allele allows normal expression of nitrogen regulated genes such as hut (Streicher et al. 1976; Bender and Magasanik 1977) while the remaining glutamine auxotrophic mutations in this linkage group $\left(\mathrm{CRM}^{-}\right)$prevented expression of hut (Prival et al. 1973; Bender and Magasanik 1977).

The recent identification in Salmonella typhimurium and Escherichia coli of a regulatory gene(s) tightly linked to glnA (Kustu et al. 1979; Pahel and Tyler 1979) raised the question of whether the defective regulatory phenotype ( $\mathrm{Reg}^{-}$) associated with the $\mathrm{CRM}^{-}$mutations in $K$. aerogenes resulted from a mutation in the structural gene or in the regulatory gene. To this end, we studied the regulatory phenotype of an amber mutation which could be assigned to $g \ln A$ unambiguously.

Offprint requests to: R.A. Bender
In preliminary studies, 23 independent glutamine auxotrophs from a large collection were tested for linkage relationships and for suppression by amber suppressors. Two of the mutations were assigned to $g \ln F$ because they were linked to $\arg G$ by P1 transduction and because their $\mathrm{Gln}^{-}$ phenotype was suppressed when any of six independent $g \ln G:: T n 5$ insertions was introduced into the strains (M. Quinto and R. Bender, unpublished observations). One mutation was assigned to $g \ln B$ because it was linked by transduction to $\mathrm{nad} B$ and because it gave rise to glutamine-independent revertants with the $\mathrm{Cn}^{\mathrm{r}}$ phenotype (Prival and Magasanik 1971). The remaining 20 mutations were linked by P1 transduction to met $B$, consistent with mutation in $g \ln A$. One of these 23 mutations, $g \ln A 3711$, showed an ambersuppressible $\mathrm{Gln}^{-}$phenotype.

glnA3711 is an Amber Mutation. Derivatives of the fertile drug-resistance plasmid RP4 carrying two different amber suppressors were used: RP4suI and RP4suIII*, which carries $\sup A 1 P 2$, a glutamine-inserting derivative of $s u \mathrm{III}$ (supF) (Faelen et al. 1977; MacNeil et al. 1978). Both plasmids carry an amber mutation in a gene required for the expression of tetracycline resistance. We used two criteria to establish that the suppressor was present in a strain: resistance to tetracycline at $15 \mu \mathrm{g} / \mathrm{ml}$ and the ability of the strain to support the growth of phage $\Phi$ GU 5 sus-151, which carries an amber-suppressible mutation. Each of these suppressor plasmids was conjugally transferred from a multiply auxotrophic E. coli donor strain (EB546 and EB547) to strain KB518 $(g \ln A 3711)$ selecting for transfer of the RP4borne kanamycin resistance in the presence of glutamine and the absence of tetracycline. After purification by single colony isolation on the same medium, these exconjugant strains, KB550 (suIII*/glnA3711) and KB551 (suI/ $\operatorname{gin} A 3711$ ), were tested and found to be prototrophic for glutamine $\left(\mathrm{Gln}^{+}\right)$and tetracycline resistant. Segregants lacking the suppressor plasmid were isolated by subculturing strains KB550 (suIII*/gln A3711) and KB551 (suI/ gln 43711 ) in the presence of glutamine and the absence of tetracycline and scoring clones for kanamycin-sensitivity. These kanamycin-sensitive segregants had regained the requirement for glutamine characteristic of the parental strain KB518, showing that the $\mathrm{Gln}^{+}$phenotype of strains KB550 and KB551 was due to suppression rather than reversion of the $g \ln A 3711$ allele. We verified this conclusion by cotransducing $g \ln A 3711$ with met $B$ into a different strain 
Table 1. Strain List

\begin{tabular}{|c|c|c|}
\hline Strain & Genotype & Source \\
\hline \multicolumn{3}{|c|}{ Klebsiella aerogenes ${ }^{\mathbf{a}}$} \\
\hline MK 9000 & wild type & $\begin{array}{l}\text { (Streicher } \\
\quad \text { et al. 1975) }\end{array}$ \\
\hline MK9011 & gln-6, ilvA1 & $\begin{array}{l}\text { (Streicher } \\
\quad \text { et al. 1975) }\end{array}$ \\
\hline KB518 & $g \ln A 3711$ & EMS of MK $9000^{b}$ \\
\hline KB550 & $\mathrm{RP} 4$ tet $^{a m}$ sup $A 1 P 2 / g \ln A 3711$ & $\mathrm{~EB} 546 \rightarrow \mathrm{KB} 518^{\mathrm{c}}$ \\
\hline KB551 & $\mathrm{RP}$ tet $^{a m_{s}}$ suI/gln $A 3711$ & $\mathrm{~EB} 547 \rightarrow \mathrm{KB} 518$ \\
\hline KB557 & $\begin{array}{l}\text { rha-1, metB4, nadB1, } \\
\quad \arg G 2\end{array}$ & $\begin{array}{l}\text { CG189 (Gaillardin } \\
\text { and Magasanik, } \\
\text { 1978) }\end{array}$ \\
\hline KB561 & $g \ln F 5081$ & NA of MK $9000^{\mathrm{d}}$ \\
\hline KB562 & $\begin{array}{l}\operatorname{gln} A 3711, \operatorname{rha}-1, \operatorname{nad} 1, \\
\quad \arg G 2\end{array}$ & $\mathrm{P} 1 \cdot \mathrm{KB} 518 \times \mathrm{KB} 557^{\mathrm{e}}$ \\
\hline KB582 & $\begin{array}{l}\mathrm{RP} 4 \text { tet }^{a m} / g \ln A 3711, \text { rha- } 1 \\
\quad \operatorname{nadB1}, \arg G 2\end{array}$ & $\mathrm{~KB} 411 \rightarrow \mathrm{KB} 562$ \\
\hline KB606 & rha-1, metB4, nadB1 & $\mathrm{P} 1 \cdot \mathrm{KB} 561 \times \mathrm{KB} 557$ \\
\hline KB656 & $\begin{array}{l}\mathrm{RP} 4 t e t^{a m} s u I / r h a-1, \text { met } B 4, \\
\quad \text { nadB1 }\end{array}$ & $\mathrm{EB} 547 \rightarrow \mathrm{KB} 606$ \\
\hline KB675 & $\begin{array}{l}\mathrm{RP} 4 \text { tet }^{a m} \text { sup } A 1 P 2 / r h a-1 \\
\quad m e t B 4, \text { nadB1 }\end{array}$ & EB546 $\rightarrow$ KB606 \\
\hline KB718 & $\begin{array}{l}\mathrm{RP} 4 t e t^{a m} \text { sup A1P2/glnA } 3711, \\
\text { rha-1, nadB1, argG2 }\end{array}$ & $\mathrm{EB} 546 \rightarrow \mathrm{KB} 562$ \\
\hline KB719 & $\begin{array}{l}\mathrm{RP} 4 \text { tet }^{a m} \text { suI/gln } A 3711 \\
\text { rha-1, nadB1, argG2 }\end{array}$ & $\mathrm{EB} 547 \rightarrow \mathrm{KB} 562$ \\
\hline KB720 & $\begin{array}{l}\text { gIn } A 3711, \text { sup-3, rha-1, } \\
\quad \operatorname{nadB1} \text {, argG2 }\end{array}$ & $\begin{array}{l}\mathrm{Gln}^{+} \mathrm{su}^{+} \text {revertant } \\
\text { of } \mathrm{KB} 562^{\mathrm{g}}\end{array}$ \\
\hline KB734 & $\begin{array}{l}\mathrm{RP} 4 \operatorname{tet}^{a m /} \operatorname{gln} A 3711 \operatorname{Rev} 1 \\
\text { rha-1, nadB1, } \arg G 2\end{array}$ & $\begin{array}{l}\mathrm{Gln}^{+} \mathrm{su}^{-} \text {revertant } \\
\text { of } \mathrm{KB} 582^{\mathrm{h}}\end{array}$ \\
\hline \multicolumn{3}{|c|}{ Escherichia coli } \\
\hline EB546 & $\begin{array}{l}\mathrm{RP} 4 \text { tet }^{a m} \text { sup A1P2/thi, thr, } \\
\text { leu, pro, met, his, str }\end{array}$ & $\begin{array}{l}\text { derived from } \\
\text { AB1 } 133^{\mathrm{f}}\end{array}$ \\
\hline EB547 & $\begin{array}{l}\mathrm{RP} 4 \text { tet }^{\text {am }} \text { suI/thi, thr, leu, } \\
\quad \text { pro, met, his, str }\end{array}$ & $\begin{array}{l}\text { derived from } \\
\text { AB1133 }\end{array}$ \\
\hline
\end{tabular}

a All $K$. aerogenes strains used are derived from strain MK53 and carry the hutC515 allele (Prival and Magasanik 1971)

b EMS, mutagenesis with ethyl methane sulfonic acid

c Arrows indicate conjugal transfer from the strain on the left to the strain on the right of the arrow

d NA, mutagenesis with nitrous acid

e Transduction mediated by phage P1clr $100 \mathrm{Km}$ (Goldberg et al. 1974). In this instance, phage grown on strain KB518 were used to transduce strain KB557

f Strain AB1133 was obtained from R. Olsen. Plasmid RP4tet ${ }^{a m}{ }_{\text {sup }}$ A1P2 (Faelen et al. 1977) was obtained from J. Schell via N. Kleckner in strain NK5310. Plasmid RP4tet ${ }^{a m}$ suI was obtained from J. Schell via D. MacNeil in strain UQ28 (MacNeil et al. 1978)

$\mathrm{g}$ The $g \ln A 3711$ allele was recovered by cotransduction with $m e t B^{+}$into strain KB557. When RP4tet ${ }^{a m}$ was introduced into strain $\mathrm{KB} 720$, all the $\mathrm{Km}^{\mathrm{R}}$ exconjugants were also $\mathrm{Tc}^{\mathrm{R}}$ proving the presence of an amber suppressor

h The $g \ln A 3711$ allele could not be recovered by cotransduction with $m e t B^{+}$into strain $\mathrm{KB} 557$. The strain remained $\mathrm{Tc}^{\mathrm{s}}$

(KB557) and showing that the glutamine requirement was suppressible by the RP4su ${ }^{+}$plasmids.

The cotransducibility of $g \ln A 3711$ with $m e t B$ was consistent with the known location of $g \ln A$ (Streicher et al. 1975). To refine the map position of $g \ln A 3711$, its linkage to $g \ln -6$, a deletion including a portion of $g \ln A$ and $g \ln G$ (Magasanik and Bender, unpublished observations) was determined. When phage P1 grown on strain KB518 ( $\ln A 3711)$ were

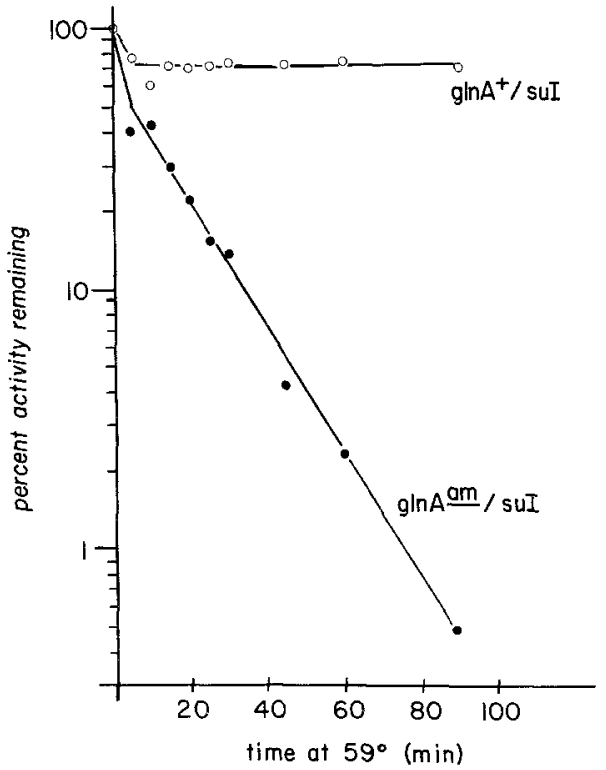

Fig. 1. Thermal inactivation of glutamine synthetase. Purified glutamine synthetase preparations from strains $\mathrm{KB} 656\left(\mathrm{gln}^{+} \mathrm{A}^{+} / \mathrm{suI}\right)$ and $\mathrm{KB} 719\left(\mathrm{~g} \ln A^{a m} / \mathrm{suI}\right)$ were diluted to a final activity of 15 units per $\mathrm{ml}$ in buffer $(20 \mathrm{mM}$ Imidazole- $\mathrm{HCl}, 10 \mathrm{mM} \mathrm{MgCl}, 2 \mathrm{mM}$ 2-mercaptoethanol, $\mathrm{pH} 7.15$ ). At $\mathrm{t}=0,0.5 \mathrm{ml}$ of each preparation was transferred to a $13 \mathrm{~mm} \times 75 \mathrm{~mm}$ test tube prewarmed in a water bath to $62^{\circ} \mathrm{C}$. The temperature of the waterbath was immediately reduced to $59^{\circ} \mathrm{C}$. Portions of the heated enzyme preparations were removed to ice-cold reaction mixture at the times indicated and glutamine synthetase activity in the $\gamma$-glutamyl transferase assay was measured later (Bender et al. 1977). The amount of enzyme activity surviving the heat treatment is presented relative to the initial activity. Closed circles represent the result with glutamine synthetase purified from strain KB719 (the amber mutant with $s u I$ present); open circles represent the result with glutamine synthetase purified from strain $\mathrm{KB} 656$ (the $g \ln A^{+}$strain with $s u$ I present). Coomassie Blue staining of SDS polyacrylamide gels of the purified preparations suggested that the specific activity of the two preparations was about equal

used to transduce strain MK9011 ( $g \ln -6$, ilvA3), several hundred colonies arose when the selection was for $\mathrm{Ilv}^{+}$ in the presence of glutamine, but none was observed when the selection was for $\mathrm{Gln}^{+}$in the presence of isoleucine, even after two days of incubation. Thus the $g \ln -6$ deletion is very close to or overlaps the gInA3711 mutational site.

glnA3711 Lies in the GS Structural Gene. If the amino acid inserted by the amber suppressor at the nonsense codon is different from the amino acid encoded by the wild type, then the resulting protein might be less stable than the wild type protein. In order to test whether the GS from a suppressed strain was more heat labile, we purified GS from a strain carrying a wild type $g \ln A$ region and from a strain carrying the $g \ln A 3711$ allele. These strains were essentially isogenic. Both strains carried the same suppressor plasmid (RP4sul) as a control against the possibility that any difference in thermostability might be caused by the suppressor or by plasmid encoded genes. Both strains were grown in the absence of glutamine with $0.1 \%$ arginine as sole nitrogen source in order to obtain derepressed levels of GS. All of the 50 clones plated from each culture just before harvesting were tetracycline resistant, assuring the presence of the suppressor in virtually all the cells. The GS from 
Table 2. Effect of amber suppressors on the $g \ln A 3711$ allele

\begin{tabular}{|c|c|c|c|c|c|c|}
\hline \multirow[t]{2}{*}{ Strain } & \multirow{2}{*}{$\begin{array}{l}\text { Relevant } \\
\text { genotype }^{b}\end{array}$} & \multirow{2}{*}{$\begin{array}{l}\text { Growth } \\
\text { medium }\end{array}$} & \multicolumn{4}{|c|}{ Enzyme activities $^{a}$} \\
\hline & & & $\begin{array}{l}\text { Glutamine } \\
\text { synthetase }\end{array}$ & $\begin{array}{l}\text { Aspara- } \\
\text { ginase }\end{array}$ & Histidase & $\begin{array}{l}\text { Glutamate } \\
\text { dehydrogenase }\end{array}$ \\
\hline \multirow[t]{2}{*}{ MK 9000} & $g \ln A^{+}$ & $-\mathrm{N}$ & 1,400 & 270 & 495 & 125 \\
\hline & & $+\mathrm{N}$ & 150 & $<3$ & 50 & 660 \\
\hline \multirow[t]{2}{*}{ KB518 } & $g \ln A^{a m}$ & $-\mathrm{N}$ & 30 & 10 & 101 & 750 \\
\hline & & $+\mathrm{N}$ & $<3$ & $<3$ & 40 & 650 \\
\hline \multirow[t]{2}{*}{ KB550 } & $s u \mathrm{III}^{*} / g \ln A^{a m}$ & $-N$ & 1,900 & 310 & 460 & 130 \\
\hline & & $+N$ & 130 & $<3$ & 60 & 670 \\
\hline \multirow[t]{2}{*}{ KB551 } & $s u \mathrm{I} / g \ln A^{a m}$ & $-\mathrm{N}$ & 540 & 190 & 470 & 90 \\
\hline & & $+\mathrm{N}$ & 80 & $<5$ & 40 & 790 \\
\hline \multirow[t]{2}{*}{ KB606 } & $g \ln A^{+}$ & $-N$ & 1,960 & 90 & 310 & 100 \\
\hline & & $+N$ & 70 & 6 & 70 & 410 \\
\hline \multirow[t]{2}{*}{ KB562 } & $g \ln A^{a m}$ & $-N$ & 10 & 5 & 50 & 390 \\
\hline & & $+\mathrm{N}$ & 3 & 5 & 30 & 350 \\
\hline \multirow[t]{2}{*}{ KB718 } & $s u \mathrm{II} I^{*} / g \ln A^{a m}$ & $-\mathrm{N}$ & 780 & 70 & 190 & 110 \\
\hline & & $+\mathrm{N}$ & 80 & 7 & 40 & 460 \\
\hline \multirow[t]{2}{*}{ KB719 } & $\operatorname{su} \mathbf{I} / g \ln A^{a m}$ & $-\mathrm{N}$ & 940 & 50 & 320 & 110 \\
\hline & & $+\mathrm{N}$ & 40 & 4 & 70 & 390 \\
\hline \multirow[t]{2}{*}{ KB675 } & $s u \mathrm{III} * / g \ln A^{+}$ & $-N$ & 700 & 80 & 370 & 100 \\
\hline & & $+\mathrm{N}$ & 50 & 3 & 40 & 310 \\
\hline \multirow[t]{2}{*}{ KB582 } & $s u^{-} / g \ln A^{a m}$ & $-\mathrm{N}$ & 4 & 4 & 60 & 330 \\
\hline & & $+\mathrm{N}$ & 1 & 2 & 40 & 430 \\
\hline \multirow[t]{2}{*}{ KB734 } & $s u^{-} / g \ln A^{a m+}$ & $-\mathrm{N}$ & 1,320 & 80 & 260 & 180 \\
\hline & & $+\mathrm{N}$ & 60 & 7 & 40 & 620 \\
\hline \multirow[t]{2}{*}{ KB720 } & $g \ln A^{\mathrm{am}} \operatorname{sup-3}$ & $-\mathrm{N}$ & 710 & 60 & 180 & 50 \\
\hline & & $+\mathrm{N}$ & 60 & 7 & 80 & 540 \\
\hline
\end{tabular}

a Cells were grown and crude extracts prepared as described previously (Bender et al. 1977). Specific activity of an enzyme is given in units per milligram of protein where one unit corresponds to the amount of enzyme producing $1 \mathrm{n} \mathrm{mol}$ of product (or consuming $1 \mathrm{n} \mathrm{mol}$ of substrate) per min at $37^{\circ} \mathrm{C}$

b Complete genotypes are listed in Table 1. Strains above the line are derived from MK9000; those below the line, from KB557

c Media were $\mathrm{W}$ salts (Bender et al. 1977) supplemented with $0.4 \%$ glucose and $0.2 \%$ L-glutamine (Calbiochem A grade, prepared immediately before inoculation) with $(+N)$ or without $(-N)$ the addition of $15 \mathrm{mM}$ ammonium sulfate. The presence of glutamine in the medium allows the accumulation of revertants and segregants so these were monitored in these cultures. Revertants were present in the KB518 cultures at less than $10^{-5}$. The derepressed $(-N)$ cultures of strains KB550 and KB551 were tested for segregants immediately before harvesting. Of $50 \mathrm{~KB} 550$ colonies tested, all retained the plasmid; of $50 \mathrm{~KB} 551$ colonies, 49 retained the plasmid and one had lost it. Strain KB718 ( $-\mathrm{N}$ culture): of 56 tested, 55 retained the plasmid intact, one had lost it; $(+\mathrm{N}$ culture): of 45 tested, 44 retained the plasmid intact, one had lost it. Strain KB719 ( $-\mathrm{N}$ culture): of 30 tested 28 retained the plasmid intact, 2 had retained the plasmid, but lost the amber suppressor from the plasmid; ( $+\mathrm{N}$ culture): of 30 tested all retained the plasmid intact. Strain KB675 ( $-\mathrm{N}$ culture): of 38 tested all retained the plasmid intact; $(+\mathrm{N}$ culture): of 42 tested all retained the plasmid intact

these strains was purified by precipitation with polyethylene glycol and acetone (Streicher and Tyler 1980). Polyacrylamide gel electrophoresis in the presence of SDS revealed one minor and four to six trace contaminants in each preparation in addition to the major GS band (not shown). The $\gamma$-glutamyl transferase activity of the enzyme preparation from the $g \ln A^{+}$strain was about $55 \%$ inhibited by $60 \mathrm{mM} \mathrm{MgCl} \mathrm{Mg}_{2}$ while that from the $g \ln A 3711$ strain was about $45 \%$ inhibited. Thus both preparations were about equal in degree of adenylylation (Bender et al. 1977). This equivalence in adenylylation was consistent with the observation that the two bands of the GS doublet on the polyacrylamide gels (representing adenylylated and non-adenylylated subunits) were about equal in intensity for both enzyme preparations (Bender and Streicher 1979).

The two enzyme preparations were diluted to the same activity and incubated at $59^{\circ}$. Samples were withdrawn to ice cold reaction mixture at various times and the $\gamma$-gluta- myl transferase activity was measured later at $37^{\circ} \mathrm{C}$. As can be seen in Fig. 1, the GS from the suppressed $g \ln A 3711$ strain was far more thermolabile than that from wild type strain. When approximately equal amounts of the two GS preparations were mixed before heat treatment, an intermediate result was obtained $(52 \%$ survival after $90 \mathrm{~min}$ of heat treatment) thus eliminating explanations such as heatactivated proteases. From these data we concluded that suppresson of $g \ln A 3711$ by $s u$ I resulted in the formation of an altered GS, thus demonstrating that $g \ln A 3711$ is a mutation in the structural gene for GS.

Strains with glnA3711 Lack Nitrogen Regulation. Wild type $K$. aerogenes responds to growth in a poor nitrogen source by derepressing a variety of enzymes including GS, an assimilatory asparaginase, and histidase (Magasanik et al. 1974; Resnick and Magasanik 1976). In addition, glutamate dehydrogenase is repressed under these conditions (Brench- 
ley et al. 1973). When a wild type strain, MK9000, and the $\operatorname{gln} A 3711$-carrying strain KB518 were grown with excess or limiting nitrogen, an obvious difference in nitrogen regulation was observed as shown in Table 2. Strain KB518 also showed no derepression of asparaginase or histidase in response to nitrogen limitation and no repression of glutamate dehydrogenase. In other words, strain KB518, which carries the gInA3711 mutation, was devoid of nitrogen regulation of asparaginase, histidase, and glutamate dehydrogenase.

Restoration of GS activity by introduction of the suppressor plasmid also led to the restoration of the normal pattern of nitrogen regulation. The relatively high derepression of GS in strain KB550 and the relatively poor derepression in strain KB551 were peculiar to this experiment (see below). Since glutamine was present and tetracycline absent from the growth medium, we were concerned that accumulation of $\mathrm{Gln}^{-}$segregants might explain the low GS values for strain KB551. Therefore we tested the nitrogen-limited cultures for segregants just before harvesting. Fifty of the fifty clones tested from strain KB550 and forty-nine of the fifty tested from strain KB551 remained Gln ${ }^{+}$. The possibility that suppressed mutant enzymes might be more or less active than wild type was also discounted since SDS polyacrylamide gels of the crude extracts showed that the band with the mobility of GS stained more intensely in the extracts from strain KB550 than in those from the wild type, while the corresponding band from the extract from strain KB551 stained less intensely than wild type, in correlation with the enzymatic activities measured. The extract from strain KB518, of course, showed only the background bands in the region corresponding to GS. No band corresponding to an amber fragment was detected.

These results were verified with another isogenic set of strains where the $g \ln A 3711$ allele had been moved into a new background (that of strain KB557) by P1 transduction. The data in the lower part of Table 2 indicated that the loss of nitrogen regulation in the $g \ln A 3711$ mutant and the restoration of nitrogen regulation when amber suppressors were present were evident even when the nonsense mutation was moved to strain KB557 in which the expression of nitrogen regulation, particularly for glutamate dehydrogenase, is consistently rather different (Table 2). We have routinely seen this difference in nitrogen regulation in all strains derived from strain MK9116.

As expected an RP4 plasmid not carrying an amber suppressor (in strain KB582) did not suppress the glutamine auxotrophy or the regulation defect and the presence of the RP4sul plasmid in a $g \ln A^{+}$strain (in strain KB675) did not alter the regulation seen in the plasmid free strain (KB606) (Table 2). In addition, two classes of $\mathrm{Gln}^{+}$revertants were characterized, a same-site revertant (KB734) and a chromosomal $\mathrm{su}^{+}$pseudorevertant (KB720). Both regained wild-type levels of GS activity and wild-type nitrogen regulation. The coreversion of the glutamine auxotrophy and the defective nitrogen regulation eliminated the hypothesis that $g \ln A 3711$ might be a double mutant with amber mutations in both $g \ln A$ and in a very tightly linked nitrogen regulatory gene.

Two conclusions can be drawn from the data presented here: (1) $\ln A 3711$ is a nonsense mutation in the structural gene for GS, and (2) the presence of the glnA3711 allele leads to loss of nitrogen regulation of enzyme formation unless nonsense suppressors are also present. Earlier work had shown that the biosynthetic activity of GS is not required for nitrogen regulation if glutamine is supplied (Bender and Magasnik 1977). The corollary that seems to follow from these conclusions (that the GS polypeptide is an essential element in nitrogen regulation) is less firm. It is, in fact, likely that there exists a regulatory gene in the $g \ln A$ operon and that $g \ln A 3711$ abolished expression of this gene by polarity (Rothstein et al. 1980). This model predicts that all $g \ln A$ mutants that make a full-length polypeptide would have nitrogen regulation and that any $g \ln A$ nonsense mutants that lost nitrogen regulation would regain it upon suppression by any nonsense suppressor. We are testing these predictions.

The $\operatorname{gin} A 3711$ allele appears to be slightly leaky in its expression, especially in strain KB518, perhaps reflecting some ribosomal misreading. It is intriguing that the residual GS activity appearing in strain KB518 is regulated by nitrogen (Table 2). The low numbers make quantitative comparisons unreliable, but the repression of GS by ammonia is qualitatively similar to that seen in wild type. Nevertheless, nitrogen regulation of histidase, asparaginase, and glutamate dehydrogenase remains seriously defective.

It should be noted that the GS present in strain KB518 was not due to an accumulation of revertants in the culture, as $\mathrm{Gln}^{+}$cells were present at less than $10^{-5}$ in this culture. Our data therefore show that translation of the GS polypeptide is required for normal regulation of genes such as the hut operons, but is probably not required for regulation of $g \ln A$. We have isolated six independent $\operatorname{Tn} 5$ insertions in a locus near $g \ln A$, all of which leave GS intact but a bolish nitrogen regulation of hut and glutamate dehydrogenase expression (M. Quinto and R.A. Bender, unpublished results), supporting the model of a regulatory gene downstream from $g \ln A$. Since these mutations suppress the $\mathrm{Gln}^{-}$ phenotype of $g \ln F$ alleles, we assume them to be the $K$. aerogenes analogues of $g \ln G$ mutations in $E$. coli (Pahel and Tyler 1979) or glnR mutations in S. typhimurium (Kustu et al. 1979).

The use of nonsense suppression of amber mutations in $g \ln A$ is a potentially powerful probe of GS structure and function. With this technique it is possible to isolate families of GS molecules with single amino acid substitutions in defined positions. As shown here, at least some such substitutions alter the physical parameters of GS.

Acknowledgements. This work was supported by research grants from the National Institutes of Health, Public Health Service (AI15822 and GM-27111). R.A.B. holds a Junior Faculty Research Award (JFRA-3) from the American Cancer Society.

\section{References}

Bender RA, Janssen KA, Resnick AD, Blumenberg M, Foor F, Magasanik B (1977) Biochemical parameters of glutamine synthetase from Klebsiella aerogenes. J Bacteriol 129:1001-1009

Bender RA, Magasanik B (1977) Regulatory mutations in the Klebsiella aerogenes structural gene for glutamine synthetase. J Bacteriol 132:100-105

Bender RA, Streicher SL (1979) Glutamine synthetase regulation, adenylylation state, and strain specificity analyzed by polyacrylamide gel electrophoresis. J Bacteriol 137:1000-1007

Brenchley JE, Prival MJ, Magasanik B (1973) Regulation of the synthesis of enzymes responsible for glutamate formation in Klebsiella aerogenes. J Biol Chem 248:6122--6128 
DeLeo AB, Magasanik B (1975) Identification of the structural gene for glutamie synthetase in Klebsiella aerogenes. $\mathrm{J}$ Bacteriol $121: 313-319$

Faelen $M$, Toussaint A, VanMontagu $M$, Elsacker S Van den, Engler G, Schell J (1977) In vivo genetic engineering: The Mu mediated transposition of chromosomal DNA segments onto transmissible plasmids. Pp 521-530 in Bukhari AI, Shapiro JA, Adhya SL (ed) DNA insertion elements, plasmids, and episomes. Cold Spring Harbor Laboratory, 1977

Gaillardin CM, Magasanik B (1978) Involvement of the $g \ln F$ gene in the autogenous regulation of glutamine synthetase formation in Klebsiella aerogenes. J Bacteriol 133:1329-1338

Goldberg RB, Bender RA, Streicher SL (1974) Direct selection for P1 sensitive mutants of enteric bacteria. J Bacteriol $118: 810-814$

Kustu S, Burton D, Garcia E, McCarter L, McFarland N (1979) Nitrogen control in Salmonella: regulation by the $g \ln R$ and $g \ln F$ gene products. Proc Nat Acad Sci USA 76:4576-4580

MacNeil T, MacNeil D, Roberts GP, Supiano MA, Brill WJ (1978) Fine structure mapping and complementation analysis of nif (nitrogen fixation) genes in Klebsiella pneumoniae. J Bacteriol $136: 253-266$

Magasanik B, Prival MJ, Brenchley JE, Tyler BM, DeLeo AB, Streicher SL, Bender RA, Paris CG (1974) Glutamine synthetase as a regulator of enzyme synthesis. In Horecker BL, Stadtman ER (ed), Current topics in cellular regulation, vol 8. Academic Press. New York pp 119-138
Pahel G, Tyler B (1979) A new glnA-linked regulatory gene for glutamine synthetase in Escherichia coli. Proc Nat Acad Sci USA 76:4544-4548

Prival MJ, Magasnik B (1971) Resistance to catabolite repression of histidase and proline oxidase during nitrogen-limited growth of Klebsiella aerogenes. J Biol Chem 246:6288-6296

Resnick AD, Magasanik B (1976) L-asparaginase of Klebsiella aerogenes, activation of its synthesis by glutamine synthetase. J Biol Chem 251:2722-2728

Rothstein DM, Pahel G, Tyler B, Magasanik B (1980) Regulation of expression from the $g \ln A$ promoter of Escherichia coli in the absence of glutamine synthetase. Proc Nat Acad Sci USA 77:7372-7376

Streicher SL, Bender RA, Magasanik B (1975) Genetic control of glutamine synthetase in Klebsiella aerogenes. J Bacteriol $121: 320-331$

Streicher SL, DeLeo AB, Magasanik B (1976) Regulation of enzyme formation in Klebsiella aerogenes by episomal glutamine synthetase of Escherichia coli. J Bacteriol 127:184-192

Streicher SL, Tyler B (1980) Purification of glutamine synthetase from a variety of bacteria. J Bacteriol 142:59-78

Communicated by G. O’Donovan

Received September 1, 1981/July 26, 1982

\section{Note Added in Proof}

While this work was in press, Gutterman et al. (J Bacteriol $150: 1314$ ) demonstrated clearly that $g \ln A$ mutations in $E$. coli cause loss of nitrogen regulation due to polar effects on downstream genes. Such downstream genes are now well-defined in E. coli, $S$. typhimurium, and $K$. aerogenes (J Bacteriol 150:1302, Mol Gen Genet 183:392, J Bacteriol 150:221). 